\title{
PRZEDSTAWICIELE ELIT SPOŁECZNYCH II RP WŚRÓD UCHODŹSTWA WOJENNEGO W IRANIE (1942-1945)
}

\author{
Jacek Pietrzak
}

(1) http://orcid.org/0000-0001-5996-6270

Uniwersytet Łódzki

\section{ABSTRACT \\ ELITES OF THE SECOND POLISH REPUBLIC AMONG THE WAR REFUGEES IN IRAN (1942-1945)}

\begin{abstract}
During the World War II Iran was an important centre of Polish war refugee communities. Members of Poland's social elites (intelligentsia and also landed gentry to a certain degree) who had experienced Soviet repressions played a key role in establishing and operating a network of Polish institutions and organisations in Iran. The author focuses on profiles of members of various professional groups and examines their significance in activity of Polish governmental apparatus (social welfare, education) as well as cultural, educational and political organisations.
\end{abstract}

Keywords: Polish refugees, Iran, World War II, social elites, intelligentsia.

Słowa kluczowe: uchodźcy polscy, Iran, II wojna światowa, elity, inteligencja.

Podczas II wojny światowej obywatele polscy stali się uczestnikami wielkich procesów migracyjnych, bezprecedensowych zarówno jeśli chodzi o skalę liczebną, jak i zasięg geograficzny. Wielu żołnierzy i cywilów, których przedwojenne doświadczenia na ogół nie wykraczały poza lokalne społeczności, znalazło się nagle w krajach uważanych za „egzotyczne”. Jednym z największych i najważniejszych ośrodków polskiego uchodźstwa wojennego stał się Iran ${ }^{1}$.

${ }^{1}$ Polskie uchodźstwo wojenne w Iranie wymaga pogłębionych badań, prowadzonych we współpracy między polskimi historykami i orientalistami, a także naukowcami irańskimi. Najważniejsze dotąd publikacje na ten temat: J. Pietrzak, Polscy uchodźcy na Bliskim Wschodzie w latach drugiej wojny światowej. Ośrodki, instytucje, organizacje, Łódź 2012, passim; J. W rób el, Uchodźcy polscy ze Zwiazku Sowieckiego 1942-1950, Łódź 2003, s. 48-93; Polacy w Iranie 1942-1945, t. 1: Antologia, oprac. A.K. Kunert, Warszawa 2002; A. Lelińska, Uchodźcy polscy w Iranie w latach 1942-1945, „Przegląd Polonijny”, R. 19, 1993, z. 1, s. 69-92; A. Kr a s now ols k a, Polacy w Iranie w czasie II wojny świato- 
W 1942 roku z obszaru Związku Sowieckiego do Iranu ewakuowano całość Polskich Sił Zbrojnych w ZSRR pod dowództwem gen. Władysława Andersa, a także część ludności cywilnej. Przeprowadzone zostały dwie główne operacje ewakuacyjne drogą przez Morze Kaspijskie (marzec-kwiecień, sierpień-wrzesień), mniejsze grupy były także ewakuowane drogą lądową (ostatnie transporty odbyły się w 1943 r.). Można przyjąć, że w wyniku tych działań przybyło do Iranu prawie 120 tys. osób, w tym około 75 tys. żołnierzy i prawie 45 tys. cywilów².

Armia została przetransportowana do Iraku, natomiast Iran pozostał miejscem pobytu ludności cywilnej. Działania zmierzające do całkowitej relokacji uchodźców, pomimo stopniowego ich ewakuowania, głównie do brytyjskich kolonii w Afryce, Indii, a od 1944 roku do Libanu, nie zostały sfinalizowane do końca wojny³. W rezultacie ustawicznych migracji liczba uchodźców ulegała zmianom. Najwięcej było ich w październiku 1942 roku - prawie 26 tys. W momencie zakończenia wojny w Europie niemal 4 tys. polskich obywateliwciąż znajdowało się w Iranie.

Największym ośrodkiem był Teheran, gdzie zorganizowano cztery obozy uchodźców. Mieszkali tam także uchodźcy, którzy przebywali poza obozami (głównie kobiety, ich liczba nigdy nie przekroczyła 2 tys.), pracując w brytyjskich i amerykańskich instytucjach wojskowych oraz w irańskich przedsiębiorstwach i domach prywatnych (np. nauczycielki lub rzadziej służące). W Isfahanie powstał unikalny ośrodek, którego celem było zapewnienie opieki i edukacji dzieciom i młodzieży. Dwa ośrodki miały charakter tranzytowy: w Meszhedzie dla ewakuowanych z ZSRR drogą lądową oraz w Ahwazie dla oczekujących na transporty z Iranu.

Zadanie zorganizowania i sprawowania opieki nad uchodźcami spoczywało na Delegaturze Ministerstwa Pracy i Opieki Społecznej (MPiOS) w Teheranie, powołano także agendy innych ministerstw. Uchodźcy organizowali różnorodne formy życia społecznego, powstały szkoły różnych szczebli oraz około 20 organizacji kulturalnych, oświatowych, naukowych, zawodowych, regionalnych i politycznych.

Uchodźstwo w Iranie posiadało charakterystyczne oblicze, wyróżniające je wśród innych skupisk polskich wojennych migrantów. Wyraźna była przewaga kobiet i dzieci ${ }^{4}$. Wśród mężczyzn większość była w wieku lub stanie zdrowia, który uniemożliwiał czynną służbę wojskową. Struktura społeczna uchodźców odzwierciedlała charakter sowieckich deportacji z lat 1939-1941, uderzających w szerokie spektrum grup społecznych ${ }^{5}$.

wej. Stereotypy i doświadczenia [w:] Dziedzictwo Odyseusza. Podróż, obcość i tożsamość, identyfikacja, przestrzeń, red. M. Cieśla-Kory tow ska, O. Pła s zczew ska, Kraków 2007, s. 369-383.

${ }^{2}$ Szerzej: J. Pietrzak, Polscy..., s. 60-83; J. Wróbe1, Uchodźcy..., s. 12-47.

${ }^{3}$ Wpływ na to miały trudności transportowe, a także opór uchodźców wobec dalszej tułaczki. Szerzej: J. Pietrzak, Polscy..., s. 84-95.

${ }^{4}$ Liczba kobiet wśród ewakuowanych jest szacowana na prawie 16 tys., dzieci (do lat 14) - niemal 15 tys. (prawdopodobnie nawet ok. 20 tys.). Zob. J. Wróbel, Uchodźcy..., s. 41.

5 D. Boćkowski, Czas nadziei. Obywatele Rzeczypospolitej Polskiej w ZSRR i opieka nad nimi placówek polskich 1940-1943, Warszawa 1999, s. 15-92; A. Głow acki, Sowieci wobec Polaków na ziemiach wschodnich II Rzeczypospolitej. 1939-1941, Łódź 1997, s. 303-403. 
Nasuwa się pytanie o miejsce przedstawicieli elit społecznych ${ }^{6}$. Po pierwszej ewakuacji zaobserwowano niewielki odsetek inteligencji wśród uchodźców ${ }^{7}$. Sytuacja uległa niewątpliwie zmianie po zakończeniu drugiej ewakuacji, jednak trudno określić, jaki procent stanowili reprezentanci inteligenckich elit. Należy także pamiętać, że znaczący odsetek polskiej inteligencji wyprowadzonej z „nieludzkiej ziemi” trafił do szeregów armii. Wydaje się, że warto pokusić się o próbę ukazania szkicu do portretu tej części diaspory, nawet jeśli będzie on niepełny. Chodzi zarówno o wskazanie reprezentatywnych przykładów przedstawicieli różnych grup społeczno-zawodowych, jak i ich roli w funkcjonowaniu aparatu państwowego oraz życia społeczno-kulturalnego, oświatowego i politycznego uchodźstwa.

Analizie poddano następujące grupy: urzędnicy administracji państwowej i samorządowej, przedstawiciele wymiaru sprawiedliwości i adwokatury, naukowcy i nauczyciele, lekarze, duchowni, dziennikarze, artyści, działacze polityczni (nieuwzględnieni w innych grupach), specjaliści i kierownicy w życiu gospodarczym, ziemianie.

Reprezentacja pracowników administracji państwowej II RP w Iranie była znacznie skromniejsza niż na przykład w Palestynie, gdzie znalazło się szereg przedstawicieli aparatu państwowego przebywających wcześniej w Rumunii. Jednak także w Iranie sporo było urzędników państwowych i samorządowych, chociaż generalnie nie najwyższego szczebla. Większość z nich zatrudniano w placówkach rządowych, gdzie cenne były ich wykształcenie i doświadczenie administracyjne.

Wśród przedstawicieli omawianej grupy można wskazać: ministra (Władysław Jaszczołt ${ }^{8}$ ), urzędników ministerstw i innych instytucji centralnych (Stanisław Widomski ${ }^{9}$, Zygmunt Krzysztoporski ${ }^{10}$, Józef Brzeski ${ }^{11}$ ), starostów (Eugeniusz Kocu-

${ }^{6}$ Przedstawiciele elit społecznych omawiani w niniejszym artykule w przytłaczającej mierze zaliczali się do inteligencji właściwej. Uwzględniono także reprezentantów ziemiaństwa, z których jednak tylko nieliczni odgrywali istotniejszą rolę w społeczności uchodźczej (i w istocie tożsamą z rolą inteligencji). Por.: J. Żar now s k i, Struktura spoleczna inteligencji w Polsce w latach 1918-1939, Warszawa 1964; idem, Inteligencja polska jako elita kulturalna i spoteczna w ostatnich stu latach, red. W. Mędrzeck i, Warszawa 2019 (Metamorfozy Społeczne, t. 24).

7 Instytut Polski i Muzeum im. gen. Sikorskiego, A 7.53/5-6, Depesza delegata rządu RP w Teheranie W. Styburskiego z 2 V 1942.

${ }^{8}$ Minister opieki społecznej (1935-1936), wcześniej wojewoda łódzki i wileński. K. Dziuda, Jaszczolt Władysław [w:] Leksykon pitsudczykowski, t. 1: Stownik biograficzny, red. J.H. Szla chetko, K. Dziuda, K. Piskała, Gdańsk 2015, s. 187-192.

9 Dyrektor Departamentu Administracyjnego Ministerstwa Skarbu, wcześniej działacz endecji, współpracownik W. Grabskiego, autor publikacji ekonomicznych. Liga Narodowa 1893-1928. Wybór relacji, oprac. T. Sikorski, A. W ą tor, Warszawa 2015, s. 197.

${ }^{10}$ Prawnik, pracownik Ministerstwa Skarbu, Naczelny Inspektor Ceł w Wolnym Mieście Gdańsku (1937-1938), pracownik Ministerstwa Odbudowy Administracji Publicznej (od 1944 r.). J. Waw rzyniak, Śrem w Powstaniu Wielkopolskim 1918-1919, Śrem 2011, s. 118; H.M. Kula, Gdańska „,dziura celna". Polscy inspektorzy celni w Wolnym Mieście Gdańsku 1920-1939, Gdańsk 1999, s. 92, 108-110, 124, 153, 164.

${ }^{11}$ Naczelnik wydziału w Prokuratorii Generalnej RP - Oddział we Lwowie. A. Redzik, Prokuratoria Skarbu - Prokuratoria Generalna Rzeczypospolitej Polskiej oddziat we Lwowie. Szkic o dziejach instytucji [w:] Lwów. Miasto, spoleczeństwo, kultura. Studia z dziejów Lwowa, t. 7: Urzędy, urzędnicy, instytucje, red. K. Kazimierczak, Ł.T. Srok a, Kraków 2010, s. 153; S. Kalbarczy k, Martyrologia 
per $^{12}$, Mieczysław Galusiński ${ }^{13}$ ), a także wyższych oficerów Policji Państwowej (Józef Torwiński ${ }^{14}$ ). Wszyscy wymienieni (z wyjątkiem Jaszczołta) znaleźli zatrudnienie w Delegaturze MPiOS. Widomski był jej kontrolerem, Krzysztoporski - kierownikiem Wydziału Społecznego, Kocuper - sekretarzem, Brzeski - kierownikiem referatu prawnego, Torwiński - szefem Wydziału Bezpieczeństwa Publicznego, a Galusiński - kierownikiem ekspozytury w Ahwazie ${ }^{15}$. Widomski objął później funkcję delegata Najwyższej Izby Kontroli, a Krzysztoporski - ministra skarbu ${ }^{16}$.

Wśród osób, które pełniły funkcje samorządowe, znalazło się czterech byłych wiceprezydentów miast wojewódzkich: Artur Szewczyk (Łódź) ${ }^{17}$, Franciszek Bała (Toruń) $^{18}$, Witold Mintowt-Czyż (Wilno) ${ }^{19}$, Michał Kolbuszowski (Lwów) ${ }^{20}$. Szewczyk był początkowo sekretarzem Delegatury, a następnie zastępcą delegata. Czyż pracował w sekretariacie Delegatury, z kolei Bała kierował ekspozyturą w Meszhedzie. Kolbuszowski angażował się w działalność społeczną ${ }^{21}$.

Przedstawiciele stosunkowo licznej grupy pracowników wymiaru sprawiedliwości często znajdowali zatrudnienie w placówkach rządowych, zwłaszcza w Komisji Badawczej Ministerstwa Sprawiedliwości, zajmującej się badaniem i dokumentowaniem przestępczości i naruszeń prawa wśród uchodźców oraz w aparacie państwowym ${ }^{22}$. Byli wśród nich: sędzia Stanisław Matula ${ }^{23}$ (przewodniczący komisji), prokurator Bohdan Kawecki ${ }^{24}$ (wiceprzewodniczący i przewodniczący komisji), sę-

Polaków w więzieniu przy ulicy Ląckiego we Lwowie w latach II wojny światowej, „Biuletyn IPN” 2010, nr 7-8, s. 109.

${ }_{12}$ Starosta zbaraski, wcześniej krasnystawski. J. Mi erzw a, Stownik biograficzny starostów Drugiej Rzeczypospolitej, t. 1, Łomianki 2018, s. 238.

${ }_{13}$ Starosta brodnicki, wcześniej kostopolski.

${ }_{14}$ Były komendant okręgów Policji Państwowej w Stanisławowie, Łodzi i Warszawie. S. Pilar sk i, Ocalony z ,,nieludzkiej ziemi” - losy inspektora Policji Państwowej Józefa Torwińskiego, „Dzieje Najnowsze", R. 47, 2015, nr 2, s. 45-56.

${ }^{15}$ Archiwum Akt Nowych (AAN), Poselstwo RP w Teheranie, 53, Obsada personalna Del. MPiOS w Teheranie, XII 1943, k. 13-15.

16 J. Pietrzak, Polscy..., s. 289-290.

${ }_{17}$ Urzędnik magistratu łódzkiego, lider łódzkiej PPS. T. La to s, Szewczyk Artur (1905-1973) [w:] Polski stownik biograficzny [PSB], t. 48, Warszawa-Kraków 2012, s. 295-297.

${ }^{18}$ K. Przybyszewski, Ludzie Torunia Odrodzonej Rzeczypospolitej (1920-1939), cz. 2: Biogramy i szkice biograficzne, Toruń 2018, s. 20-22.

19 J. Żej mo, Czyż Witold (1884-1952) [w:] Stownik biograficzny działaczy polskiego ruchu robotniczego [SBDPRR], t. 1, Warszawa 1978, s. 376.

${ }^{20}$ G. Mazur, Życie polityczne polskiego Lwowa 1918-1939, Kraków 2007, s. 28-29, 35-36, 285286.

${ }^{21}$ Prezes Koła Lwowian i Ziem Południowo-Wschodnich, członek zarządu Stowarzyszenia Inżynierów i Techników. J. Pietrzak, Polscy..., s. 451-452.

${ }^{22}$ Ibidem, s. 285-288.

${ }^{23}$ Sędzia Sądu Apelacyjnego w Katowicach. L. Krzyżanowski, Sędziowie II Rzeczypospolitej. Okręgi apelacyjne: krakowski i katowicki, Katowice 2011, s. 212.

${ }^{24}$ Prokurator i adwokat w Wilnie. [Kawecki Bohdan] [w:] Archiwum Korporacyjne. Archiwum i Muzeum Polskich Korporacji Akademickich, www.archiwumkorporacyjne.pl/index.php/muzeum-korporacyjne/wilno/k-cresovia/ [dostęp: 9 IV 2020 r.]; B. K a w eck i, Ze wspomnień wileńskiego prokuratora, Londyn 1977. 
dzia Jan Morelowski ${ }^{25}$ (członek komisji). Sędziowie i prokuratorzy pracowali także w innych placówkach rządowych. Sędzia Józef Auber był zastępcą sekretarza Delegatury $\mathrm{MPiOS}^{26}$, prokurator Witold Matkowski urzędnikiem Wydziału Bezpieczeństwa Publicznego Delegatury MPiOS, a w 1945 roku szefem Placówki Ministerstwa Spraw Wewnętrznych ${ }^{27}$. Sędzia Kazimierz Abramowicz działał zaś społecznie jako prezes Koła Prawników Polskich ${ }^{28}$.

Niektórzy z przedstawicieli palestry byli zarazem czynnymi działaczami politycznymi. Zawód adwokata wykonywali między innymi czołowi działacze Stronnictwa Narodowego w Iranie ${ }^{29}$ : Jan Aleksandrowicz ${ }^{30}$ (Sanok), Olgierd Daniłłowicz ${ }^{31}$ (Grodno), Dominik Maciejko ${ }^{32}$ (Lwów), Adam Treszka ${ }^{33}$ (Lwów). Adwokatami byli także działacze PPS Otton Pehr $^{34}$ (Grudziądz) oraz Wacław Goldman ${ }^{35}$ (Warszawa), zastępca delegata NIK. Wśród znaczących postaci palestry można także wskazać Józefa Zaścińskiego ${ }^{36}$ (Łuck) oraz Adolfa Tillesa ${ }^{37}$ (Kraków).

Niewątpliwie jednym z najważniejszych osiągnięć uchodźstwa w Iranie było zorganizowanie i prowadzenie różnorodnych form działalności edukacyjnej i naukowej. Obecność wśród uchodźców grupy uczonych głównie ze szkół wyższych Wilna i Lwowa ${ }^{38}$, reprezentujących różne dyscypliny naukowe, umożliwiła realizację jednego z najciekawszych i najbardziej wartościowych przedsięwzięć polskiego

${ }^{25}$ Naczelnik Sądu Grodzkiego w Żółkwi. J. Morelow ski, Sędzia za kratami. Wspomnienia z lat 1939-1942, Nowy York 1970; B. Wi erzbiań s k i, Stowo wstęne [w:] J. Morelow s ki, Poezje, Nowy York 1988, s. 4-6.

${ }^{26}$ Sędzia Sądu Okręgowego w Krakowie. L. Krzyżanowski, Sędziowie..., s. 348, 354-355; J. Pietrzak, Polscy..., s. 192, 448.

27 Wiceprokurator Sądu Okręgowego w Stanisławowie. Placówka MSW zajmowała się m.in. badaniem nastrojów politycznych. J. Pietrzak, Polscy..., s. 193, 279.

${ }^{28}$ Sędzia śledczy Sądu Okręgowego w Wilnie. [Abramowicz Kazimierz] [w:] Album Polonorum, t. 1, www.konwentpolonia.pl/album-polonorum/kazimierz-abramowicz [dostęp: 9 IV 2020 r.]; A.K. Ku nert (oprac.), Polacy... s. 387.

${ }^{29}$ Szerzej o SN w Iranie zob.: K. Kaczmarski, O Wielka Polskę na wojennym wychodźstwie. Stronnictwo Narodowe wobec rzadu gen. Władysława Sikorskiego (1939-1943), Rzeszów 2013, s. 340353; J. Pietrzak, Polscy..., s. 371-378.

${ }^{30}$ Był m.in. wiceprzewodniczącym Komisji Badawczej oraz prezesem Miejskiego Komitetu Obywatelskiego w Teheranie. K. Ka czmars ki, O Wielka Polskę.., s. 344; J. Pietrzak, Polscy..., s. 286288, 372-378, 453.

${ }^{31}$ K. Kaczmarski, O Wielka Polske..., s. 344.

${ }^{32}$ Ibidem, s. 342.

33 Ibidem, s. 342-343; „Biuletyn. Koło Lwowian” 1984, nr 48, s. 1-6.

${ }^{34}$ W. S zy s zk ow sk i, Pehr Otton Karol (1892-1963) [w:] PSB, t. 25, Wrocław 1980, s. 541-542.

35 A.K. Kun ert, Goldman Wactaw [w:] SBDPRR, t. 2, Warszawa 1987, s. 292.

${ }^{36}$ Dziekan Rady Adwokackiej w Łucku. F. Ry mar z, Adwokatura lubelska w okresie dwudziestolecia międzywojennego (1918-1939), „Palestra” 1988, t. 32, nr 7(367), s. 21-23, 27 (tu błędna informacja, że zginął w 1939).

${ }^{37}$ Kierował kursem prawno-administracyjnym w Teheranie. W. Wincła w s k i, Stownik biograficzny socjologii polskiej, t. 4, Toruń 2011, s. 99; A.K. Ku nert (oprac.), Polacy..., s. 355.

${ }^{38}$ Szerzej o represjach sowieckich wobec naukowców: S. Kalbarczyk, Polscy pracownicy na$u k i$ - ofiary zbrodni sowieckich w latach II wojny światowej: zamordowani, więzieni, deportowani, Warszawa 2001. 
uchodźstwa wojennego. Chodzi o Towarzystwo Studiów Irańskich (TSI) powołane 19 października 1942 roku w Teheranie ${ }^{39}$. Założycielami towarzystwa byli: Stanisław Kościałkowski ${ }^{40}$, Wiktor Sukiennicki ${ }^{41}$, Stanisław Swianiewicz, ${ }^{42}$, Zygmunt Klemensiewicz $^{43}$, Czesław Czarnowski ${ }^{44}$, Stanisław Krystyn Zaremba ${ }^{45}$. Kościałkowski, prezes TSI nieprzerwanie od października 1942 roku do kwietnia 1945 roku, był niewątpliwie najważniejszą postacią w historii towarzystwa ${ }^{46}$. Wśród pozostałej kadry naukowej szczególnie istotną rolę odgrywał Franciszek Machalski, sekretarz i ostatni prezes $\mathrm{TSI}^{47}$. Wśród młodszych pracowników nauki zaangażowanych w TSI można wyróżnić również takie postacie jak Adam Bardecki ${ }^{48}$ oraz Wiktor Turek ${ }^{49}$. Jednym z uczonych, którzy nie byli zaangażowani w prace TSI, był Jakub Węgierko, lekarz internista, docent Uniwersytetu Warszawskiego ${ }^{50}$.

39 Szerzej: J. Drau s, Towarzystwo Studiów Irańskich w latach 1942-1945, „Roczniki Nauk Społecznych" 1985, t. 13, z. 2, s. 59-72; M.A. S u pruniu k, Nauka polska na Bliskim i Środkowym Wschodzie w latach 1942-1949, cz. I: Persja, „Opuscula Musealia” 2014, t. 22, s. 45-71.

${ }^{40}$ Historyk, profesor Uniwersytetu Stefana Batorego w Wilnie. Stanisław Kościatkowski pamięci przywrócony, red. M. Dą brow ska, Warszawa-Łódź 2016, passim.

${ }^{41}$ Prawnik, sowietolog, prof. USB. M. Kornat, Sukiennicki Wiktor (1901-1983) [w:] PSB, t. 45, Warszawa-Kraków 2008, s. 396-401.

42 Prawnik, ekonomista, sowietolog, prof. USB. M. Kornat, Swianiewicz (Świaniewicz) Stanisław (1899-1997) [w:] PSB, t. 46, Warszawa-Kraków 2009, s. 124-129.

${ }^{43}$ Fizykochemik, prof. Politechniki Lwowskiej, taternik. S. Brzozow ski, J. S zpilecki, Klemensiewicz Zygmunt Aleksander (1886-1963) [w:] PSB, t. 12, Wrocław 1967, s. 598-600; Z. R a d w ań sk a- Pary ska, W.H. Pary sk i, Wielka encyklopedia tatrzańska, Poronin 2004, s. 517-518. Był także kierownikiem tzw. czołówki fotograficznej w Wydziale Kulturalno-Oświatowym Delegatury MPiOS.

${ }^{44}$ Lekarz otolaryngolog, prof. USB, żeglarz. C. C z a rn ow s ki, Strzępy wspomnień. Szkice autobiograficzne, Warszawa 1973; S. Kalbarczy k, Polscy pracownicy nauki..., s. 78.

${ }_{45}$ Matematyk, doc. UJ, taternik. Z. Radwań sk a-Pary ska, W.H. Pary ski, Wielka encyklopedia tatrzańska, s. 1391-1392; S. D om oradzk i, M. Staw is ka, Distinguished Graduates in Mathematics of Jagiellonian University in the Interwar Period. Part II: 1926-1939, „Technical Transactions. Fundamental Sciences. Czasopismo Techniczne. Nauki Podstawowe" 2015, z. 2-NP (20), s. 119-121.

${ }_{46}$ M.A. Supruniuk, Naukowa i polityczna działalność Stanisława Kościałkowskiego na Środkowym i Bliskim Wschodzie w latach 1942-1949 [w:] Stanisław Kościatkowski..., s. 193-214.

${ }^{47}$ Filolog, orientalista, asystent Uniwersytetu Jana Kazimierza we Lwowie, nauczyciel gimnazjum w Tarnopolu; w Iranie był także współpracownikiem Centrum Informacji na Wschodzie, prezesem Koła Literackiego, działaczem Związku Harcerstwa Polskiego na Wschodzie; po wojnie prof. UJ, wybitny iranista. F. Machalski, Z ziemi perskiej do Polski. Wybór tekstów, wstęp i oprac. K. i K. Paraskiewi c z, Kraków 2016 (biogram: s. 15-33); A. Kras now olsk a, Machalski Franciszek (1904-1979) [w:] Encyclopaedia Iranica, www.iranicaonline.org/articles/machalski-franciszek [dostęp: 30 III 2020 r.]; F. Machalski, Wędrówki irańskie, Warszawa 1960.

${ }^{48}$ Psycholog, asystent UJK. J. Drau s, Uniwersytet Jana Kazimierza we Lwowie w latach 1939 1944, „Prace Komisji Historii Nauki PAU” 2006, t. 7, s. 107; S. Porta1s k i, Zarys historii Polskiego Towarzystwa Naukowego na Obczyźnie, Londyn 2009, s. 49-50; M.A. S u pru ni u k, Nauka polska..., s. 64.

${ }^{49}$ Prawnik, specjalista prawa międzynarodowego, asystent UJK. Był także zastępcą kierownika Wydziału Kulturalno-Oświatowego Delegatury MPiOS. A. B rożek, Turek Wiktor [w:] Stownik historyków polskich, red. M. Prosińska-Jack1, Warszawa 1994, s. 531-532; B. Heydenkorn, Wiktor Turek (1910-1963), „Canadian Slavonic Papers” 1964, vol. 6, s. 99-100; J. Dra u s, Uniwersytet Jana Kazimierza..., s. 108; M.A. S u prun iu k, Nauka polska ..., s. 57, 60; A.K. Ku nert (oprac.), Polacy..., s. 271.

${ }^{50}$ A. Ś ródka, Wspomnienia pośmiertne: Jakub Węgierko (1889-1960), ,Rocznik Towarzystwa Naukowego Warszawskiego" 1983, t. 46, s. 298-303. 
Nauczyciele uchodźcy odegrali szczególnie ważną rolę społeczną, organizując i prowadząc nauczanie szkolne na różnych szczeblach oraz opiekę nad dziećmi ${ }^{51}$. Do najbardziej zasłużonych organizatorów oświaty należał Jakub Hoffman, legionista, nauczyciel i kierownik szkół powszechnych, działacz kulturalno-oświatowy na Wołyniu, poseł na Sejm. Początkowo był on zastępcą szefa ekspozytury w Isfahanie, a następnie szefem Wydziału Kulturalno-Oświatowego i Szkolnego w Delegaturze MPiOS w Teheranie ${ }^{52}$. Kierownicy aparatu oświatowego byli doświadczonymi nauczycielami szkół różnych szczebli. Delegaturą Urzędu Oświaty i Spraw Szkolnych, a następnie Ministerstwa Wyznań Religijnych i Oświecenia Publicznego kierowali kolejno Stanisław Rzerzycha ${ }^{53}$ oraz Piotr Piałucha ${ }^{54}$. Wizytatorem szkół średnich był Stanisław Sztaba ${ }^{55}$. Wśród nauczycieli ośrodka teherańskiego można wspomnieć Wandę Szuszkiewicz-Górszczyk ${ }^{56}$ i Henryka Piekarskiego ${ }^{57}$, zarazem prezesów Zrzeszenia Nauczycieli Polaków. Do zasłużonych nauczycieli w Isfahanie należeli: Maria Krzyżanowska ${ }^{58}$, Maria Gerstman ${ }^{59}$, Adam Lorenowicz ${ }^{60}$, Dominik Pytel ${ }^{61}$, Stefan Juzwa ${ }^{62}$.

Stosunkowo niewiele wiadomo o lekarzach, którzy zmagali się z dramatyczną (zwłaszcza w pierwszych miesiącach) sytuacją zdrowotną uchodźców. Można wymienić takie postacie jak Emil Skulski (kierownik Wydziału Służby Zdrowia Delegatury

${ }_{51}$ Szerzej: J. Dra u s, Oświata i nauka polska na Bliskim i Środkowym Wschodzie 1939-1950, Lublin 1993, s. 54-67, 84-113; Isfahan - miasto polskich dzieci, red. I. B e a u pré-S ta nki ew i cz, D. Waszczuk-Kamieniecka, J. Lewicka-Howells, Londyn 1987, passim.

${ }^{52}$ A. Milew ska-Młynik, Jakub Hoffman - Wotyniak z wyboru, spotecznik z powolania, „Wrocławskie Studia Wschodnie” 2010, t. 14, s. 141-167; J. Pi etrzak, Parlamentarzyści II Rzeczypospolitej Polskiej na tułaczych szlakach Bliskiego Wschodu [w:] Druga Rzeczpospolita i nie tylko. Ludzie, środowiska, idee. Profesorowi Pawłowi Samusiowi w 70 rocznicę urodzin-uczniowie, red. J. P i etrzak, Łódź 2016, s. 199.

${ }_{53}$ Nauczyciel geografii w gimnazjum w Tłumaczu, na początku wojny w szkolnictwie polskim na Węgrzech. J. Drau s, Oświata i nauka polska..., s. 62-63, 66.

${ }_{54}$ Kierownik szkół powszechnych, inspektor szkolny w woj. wileńskim; w Iranie wizytator szkół powszechnych i przew. Komisji Szkolnej Delegatury MPiOS. J. D ra u s, Oświata i nauka polska ..., s. 54, $62,65,68$.

${ }^{55}$ Nauczyciel seminarium nauczycielskiego w Stanisławowie; przewodniczący Komisji Szkolnej Delegatury MPiOS oraz tymczasowy delegat UOiSS. J. D rau s, Oświata i nauka polska..., s. 55, 62.

${ }_{56}$ Absolwentka Uniwersytetu Poznańskiego (wychowanie fizyczne, pedagogika, socjologia); działaczka Stronnictwa Ludowego. M. De me 1, Pamięci Wandy Szuszkiewicz-Ferens (1912-2000), „Kultura Fizyczna" 2002, nr 9-10, s. 25-29; J. Pietrzak, Polscy..., s. 380-385, 450-451.

${ }^{57}$ Fizyk, b. dyrektor gimnazjum w Lidzie, dyrektor gimnazjum w Teheranie. H. P i ek arski, Znad Niemna przez Syberię do Kanady, Roma 1967.

${ }^{58}$ Nauczycielka geografii i przyrody w gimnazjach żeńskich w Przemyślu; dyrektor gimnazjum w Isfahanie. Isfahan ..., s. 217-219.

${ }_{59}$ Nauczycielka języków obcych, dyrektor gimnazjum krawieckiego w Isfahanie; współpracowniczka TSI. Ibidem, s. 191-192.

${ }^{60}$ Nauczyciel przedmiotów ścisłych w gimnazjum w Mysłowicach; nauczyciel gimnazjum i inspektor szkolny w Isfahanie. J. Dra u s, Oświata i nauka polska ..., s. 63, 104.

${ }^{61}$ Nauczyciel języków klasycznych, b. dyrektor gimnazjum w Tarnopolu, nauczyciel gimnazjum i inspektor szkolny w Isfahanie. Ibidem, s. 63.

${ }^{62}$ Nauczyciel matematyki w gimnazjum w Tarnopolu; komendant hufca harcerskiego w Isfahanie. Isfahan..., s. 249-253. 
MPiOS) ${ }^{63}$, Józef Weyland (inspektor sanitarny) ${ }^{64}$, Mieczysław Srokowski (komendant Szpitala PCK w Teheranie) ${ }^{65}$, Zygmunt Grębecki (dyrektor Głównego Szpitala Cywilnego w Teheranie) ${ }^{66}$, Jan Rogowski (kolejny dyrektor tego szpitala) ${ }^{67}$, Włodzimierz Deutscher (naczelny lekarz Obozu nr $1 \mathrm{w}$ Teheranie, kierownik poradni PCK $)^{68}$.

Duszpasterstwo uchodźcze odzwierciedlało wielowyznaniowe oblicze diaspory. Wśród duchownych rzymskokatolickich na wyróżnienie zasługują takie postacie jak ks. Władysław Słapa, kierownik duszpasterstwa, dyrektor Akcji Katolickiej ${ }^{69}$, ks. Jan Achtabowski, zastępca kierownika duszpasterstwa ${ }^{70}$, oraz ks. Franciszek Tomasik, duszpasterz ośrodka w Isfahanie ${ }^{71}$. Czołowym duchownym greckokatolickim był ks. Jan J. Jaworski, który angażował się także w działalność społeczno-polityczną (lider Komitetu Starorusinów, działacz SN) ${ }^{72}$. Największą rolę wśród duchowieństwa prawosławnego odegrał ks. Michał Bożerianow, który nie tylko kierował duszpasterstwem, ale także był przywódcą społeczności białoruskiej (przewodniczący Komitetu Białoruskiego $)^{73}$.

$\mathrm{W}$ Iranie, podobnie jak $\mathrm{w}$ innych ośrodkach polskiej diaspory na Bliskim Wschodzie, wydawano wiele różnego rodzaju czasopism ${ }^{74}$, jednak kadra profesjonalnych dziennikarzy i publicystów była nieliczna ${ }^{75}$. Można tu wyróżnić takie postacie

${ }^{63}$ Naczelny lekarz Ubezpieczalni Społecznej w Drohobyczu. AAN, Pos. RP w Teheranie, 53, Obsada, k. 15.

${ }^{64}$ Kierownik referatu sanitarnego Starostwa Grodzkiego w Łodzi. Ibidem.

${ }^{65}$ Chirurg szpitala PCK w Warszawie, uczestnik obrony Warszawy 1939. A.K. Kun ert (oprac.), Polacy..., s. 91.

${ }^{66}$ Lekarz Samodzielnej Brygady Strzelców Karpackich (SBSK). M. Kruszyński, The State of Health of Poles Evacuated from Russia to Persia in 1942, „Antemurale” 1976, vol. 20, s. 137.

${ }^{67}$ Przew. sekcji lekarskiej TSI, zmarł w 1944. J. D ra u s, Towarzystwo Studiów Irańskich ..., s. 61-62.

${ }^{68}$ Internista w klinice UW, zmarł w 1943 r. A.K. Ku unert (oprac.), Polacy..., s. 283.

${ }^{69}$ Były kapelan Samodzielnej Brygady Strzelców Karpackich. A. Judycki, Polscy duchowni w świecie. Stownik biograficzny, t. 1, Kielce 2008, s. 360; J. Pietrzak, Polscy..., s. 461-463; A.K. Kunert (oprac.), Polacy..., s. 173, 184-185.

${ }^{70}$ Kapłan diecezji chełmińskiej, kapelan WP. J. Walk u s z, Niezłomny żołnierz na Bożym posterunku. Ks. Jan Achtabowski 1909-1998, „Duszpasterz Polski Zagranicą” 1999, t. 50, nr 3, s. 405-410.

${ }^{71}$ Salezjanin, dyrektor sierocińca w Supraślu. T. Krahe1, Ks. Franciszek Tomasik-salezjanin z Supraśla, „W Służbie Miłosierdzia” 2006, nr 1, www.wsm.archibial.pl/wsm16/art.php?id_artykul=195 [dostęp: 18 IV 2020 r.]; Isfahan ..., s. 219-220.

72 Działacz tzw. ruchu staroruskiego, przeciwnik narodowego ruchu ukraińskiego, poseł na Sejm. J. Pietrzak, Parlamentarzyści..., s. 199-200.

${ }^{73}$ A. Mironowicz, Działalność ks. Michała Bożerianowa na terenie Iranu i Afryki Wschodniej w latach 1941-1945, „Białoruskie Zeszyty Historyczne” 2014, t. 42, s. 137-165.

${ }^{74}$ Szerzej: O.S. Czarnik, $W$ drodze do utraconej Itaki. Prasa, ksiązki, czytelnictwo na szlaku Samodzielnej Brygady Strzelców Karpackich (1940-1942) oraz Armii Polskiej na Wschodzie i 2 Korpusu (1941-1946), Warszawa 2012, s. 119-127, 466-467; P. S zulc, Czasopiśmiennictwo polskie w Iranie w latach 1942-1945, „Dzieje Najnowsze” 2018, R. 50, nr 2, s. 49-69.

${ }^{75}$ Większość dziennikarzy polskich na Bliskim Wschodzie pracowała w prasie wojskowej lub cywilnej w Palestynie. 
jak Bronisław Skalak ${ }^{76}$, Tadeusz Ehrenberg ${ }^{77}$ oraz Roman Boski ${ }^{78}$. Pełnili oni kolejno funkcję redaktora pisma „Polak w Iranie” wydawanego przez Delegaturę MPiOS, Boski kierował także Wydziałem Prasowym delegatury.

Wśród przedstawicieli świata artystycznego uwagę zwracała grupa cenionych plastyków. Roman Schneider, architekt wnętrz, rzeźbiarz i ceramik, razem z żoną powołał i prowadził Polską Wytwórnię Artystyczną w Teheranie. Zajmował się między innymi projektami wnętrz różnych instytucji irańskich, brytyjskich i amerykańskich w irańskiej stolicy, pracował dla rodziny szacha, zorganizował produkcję lalek podarunkowych. Był także prezesem Związku Zawodowego Polskich Artystów Plastyków w Iranie ${ }^{79}$. Aktywni artystycznie byli także malarze ${ }^{80}$, np. Mary (Mery) Schneider (także graficzka) ${ }^{81}$, Bolesław Baake ${ }^{82}$ oraz Stefan Felsztyński ${ }^{83}$. Świat muzyczny reprezentowali pianiści Adam Kapuściński ${ }^{84}$ oraz Fryderyk Portnoj ${ }^{85}$.

Należy także wspomnieć o grupie osób, które można określić mianem zawodowych działaczy społeczno-politycznych. W grupie tej można wskazać dawnych robotników, którzy poprzez działalność w związkach zawodowych i partii politycznej (PPS) trafiali do warstwy inteligenckiej. Była to nieliczna grupa, ale odgrywająca ważną rolę w funkcjonowaniu kontrolowanego przez PPS aparatu opieki społecznej ${ }^{86}$. Reprezentantami tej grupy byli Franciszek Haluch, zastępca delegata, a następnie najdłużej urzędujący delegat MPiOS (III 1943 - VIII 1944) ${ }^{87}$ oraz Antoni Pająk (zastępca delegata) $)^{88}$.

${ }^{76}$ Lider lwowskiej PPS, redaktor „Dziennika Ludowego”. W Teheranie prezes Komitetu Politycznego PPS i kontroler Delegatury MPiOS. A. Pacholczy kowa, Skalak (wczéśniej Skaluk) Bronistaw (1892-1949) [w:] PSB, t. 37, Warszawa-Kraków 1996, s. 628-629; J. Pi ietrzak, Polscy..., s. 177, 191, 386-389; A.K. Kunert (oprac.), Polacy..., s. 306.

77 Dziennikarz „Gazety Polskiej”. Zmarł w 1943 r. A.K. Kunert (oprac.), Polacy..., s. 335.

78 Dziennikarz „Robotnika”, działacz PPS, wiceprezes Syndykatu Dziennikarzy Warszawskich. A. Pacholczy kow a, Boski-Getlicherman Roman [w:] SBDPRR, t. 1, s. 23.

79 J. Daranowska-Łukaszewska, Sznajder (Schneider, Szneider) Roman (1889-1969) [w:] PSB, t. 48, Warszawa-Kraków 2012, s. 454-456; A.K. Ku uert (oprac.), Polacy..., s. 95, 375.

80 J.W. Sienkiewi cz, Wyprowadzeni z nieludzkiej ziemi: artyści wokół Andersa, „Sztuka Europy Wschodniej” 2014, t. 2, s. 409-411.

${ }^{81}$ J. Daranowska-Łukaszewska, Sznajder (Litauer-Schneider, Litauer-Schnajder, Litauer-Szneider) Mary (Mery) (1900-1992) [w:] PSB, t. 48, Warszawa-Kraków 2012, s. 452-454.

${ }^{82}$ M. Kuhnke, Cenne, bezcenne, pozyskane, „Cenne, Bezcenne, Utracone” 2002, nr 5, s. 5; M.A. Supruniuk, Nauka polska..., s. 63, 66; A.K. Kunert (oprac.), Polacy..., s. 326, 336.

${ }^{83}$ Legionista, oficer WP, aktor, publicysta. W.K. Cygan, Oficerowie Legionów Polskich 19141917. Stownik biograficzny, t. 1, Warszawa 2005, s. 276-278; A.K. Kunert (oprac.), Polacy..., s. 60, 326; J.W. Si ienkiewicz, Wyprowadzeni..., s. 410-412.

${ }^{84}$ A.K. Kunert (oprac.), Polacy..., s. 69, 131, 293, 382.

${ }^{85}$ L.T. Błaszczyk, Żydzi w kulturze muzycznej ziem polskich w XIX i XX wieku. Stownik biograficzny, Warszawa 2014, s. 200; A.K. Ku nert (oprac.), Polacy..., s. 69, 131.

${ }^{86}$ Szerzej: D. Urzyńska, Powstanie polskich struktur politycznych w Iranie w czasie II wojny światowej (na przyktadzie Polskiej Partii Socjalistycznej), ,Przegląd Wschodni” 2002, z. 1, s. 137-154.

${ }^{87}$ Długoletni górniczy działacz związkowy z zagłębia borysławskiego. Biblioteka Polska w Londynie, Archiwum Osobowe Emigracji [BPOSK, AOE], 41/63; A.K. Kun ert, Haluch Franciszek (1893-1963) [w:] SBDPRR, t. 2, s. 461-462; J. Pietrzak, Polscy..., s. 185-204.

${ }^{88}$ Legionista, działacz PPS (Biała Krakowska) i kombatancki, poseł na Sejm. A. Pilch, Pająk Antoni (1893-1965) [w:] PSB, t. 25, Wrocław 1980, s. 22-23; J. Pietrzak, Parlamentarzyści..., s. 200; In- 
Wśród „zawodowych” działaczy politycznych byli także ludowcy ${ }^{89}$. Franciszek Wilk, członek Rady Narodowej, był organizatorem struktur Stronnictwa Ludowego w Iranie ${ }^{90}$. Po jego wyjeździe do Palestyny kierownictwo organizacji objął Jerzy Mikołaj Górszczyk, który pełnił także funkcję szefa placówki MSW (II 1943 - I 1945) ${ }^{91}$.

Dla aparatu opiekuńczego, który stał się rozbudowaną i skomplikowaną machiną, przydatne były wiedza fachowa i doświadczenie różnego typu specjalistów zatrudnionych przed wojną $\mathrm{w}$ instytucjach życia gospodarczego. Można wśród nich odnaleźć bankowców, kierowników zakładów przemysłowych, transportowych i handlowych, inżynierów i techników. Większość z nich rekrutowała się z szeregów uchodźstwa, ale kilka osób zostało oddelegowanych z Wielkiej Brytanii. Był wśród nich bankowiec Wiktor Styburski, pierwszy szef Delegatury MPiOS, bardzo zasłużony w organizacji aparatu opiekuńczego ${ }^{92}$. Jego zastępcą był krótko inżynier górnik i geolog Stefan Daszyński ${ }^{93}$. Inny wysłannik z Londynu, Feliks Kollat, dyrektor armatora „Żegluga Polska”, kierował Wydziałem Transportowym przy Poselstwie RP, który zajmował się realizacją dostaw zaopatrzenia, a także sprawował ważną funkcję delegata $\mathrm{PCK}^{94}$.

Doświadczenie gospodarcze lub techniczne mieli także organizatorzy ośrodków uchodźczych poza Teheranem. Tadeusz Dymowski, prawnik, ekonomista, działacz gospodarczy (oraz polityczny) był organizatorem i kierownikiem ośrodka w Isfahanie $^{95}$. Juliusz Wierciński, inżynier, szef polskiej delegacji w Radzie Portu i Dróg Wodnych w Wolnym Mieście Gdańsku, kierował ośrodkiem w Ahwazie ${ }^{96}$. Stosunkowo liczna grupa specjalistów gospodarczych i technicznych pracowała także w centrali delegatury $\mathrm{w}$ Teheranie ${ }^{97}$. Ostatnim jej szefem był kierownik firmy naftowej z Borysławia Stanisław Pokładzki ${ }^{98}$.

W środowisku ziemian kresowych aktywnością wyróżniały się postacie angażujące się przed wojną w działalność społeczno-polityczną. Michał Tyszkiewicz pracował

wentarz Akt Antoniego Pająka (premiera rządu Rzeczypospolitej Polskiej na uchodźstwie) i jego rodziny z lat 1919-2001, oprac. E. Koło dzi j, B. Now oży c ki, Warszawa 2008.

${ }^{89}$ Szerzej: R. Buc zek, Stronnictwo Ludowe w latach 1939-1945. Organizacja i polityka, Londyn 1975, s. 426-446.

${ }^{90}$ Polonista, absolwent UJK, był czołowym działaczem środowiska lwowskiego Polskiej Akademickiej Młodzieży Ludowej, Związku Młodzieży Wiejskiej RP „Wici” oraz Stronnictwa Ludowego. R. Wi tale c, Franciszek Wilk 1914-1990. Biografia ludowca niezłomnego, Rzeszów-Warszawa 2015.

91 Właściwie Mikołaj Poleszczuk. Działacz „Wici”, PAML, Stronnictwa Chłopskiego (Władysława Dobrocha); publicysta. Stownik biograficzny działaczy ruchu ludowego, Warszawa 1989, s. 128; J. Pi etrzak, Polscy..., s. 277-279, 381-385.

92 Wicedyrektor w Banku Polskim, zasłużony w akcji ratowania polskiego złota. Był także delegatem Ministerstwa Skarbu. BPOSK, AOE, sygn. 641/72; J. P i etrzak, Polscy..., s. 176-188, 289.

93 Syn Ignacego, wybitny alpinista. Z. Radwańska-Paryska, W.H. Paryski, Wielka encyklopedia tatrzańska, s. 204-205.

${ }^{94}$ Feliks Kollat (1895-1975), „Polska Gazeta Transportowa” 2005, nr 26, s. 8; J. Pietrzak, Polscy..., s. 148, 495-497.

95 J. Pietrzak, Parlamentarzyści..., s. 201; Isfahan ..., s. 115-116, 118, 137, 145-146, 174.

96 J. Pietrzak, Polscy..., s. 195.

${ }^{97}$ AAN, Pos. RP w Teheranie, 53, Obsada, k. 33-35.

${ }_{98}$ BPOSK, AOE, 163/67. 
jako attaché w poselstwie w Teheranie ${ }^{99}$, Konstanty Rdułtowski był kierownikiem działu Biura Adresowego Uchodźstwa Polskiego PCK (Centralne Biuro Ewidencji Obywateli Polskich na Wschodzie) ${ }^{100}$. W działalność społeczno-polityczną był także zaangażowany Tadeusz Dworakowski ${ }^{101}$. Ziemianie ci byli założycielami działaczami Zespołu Pracy nad Odbudową Polski, organizacji łączącej elementy umiarkowanej tradycji konserwatywnej i piłsudczykowskiej ${ }^{102}$.

$$
* * *
$$

Warto zauważyć, że stworzone od podstaw swego rodzaju „państwo uchodźcze” było dziełem samych migrantów. Można powiedzieć, że specyfika funkcjonowania diaspory w Iranie, biorąc pod uwagę doświadczenia sowieckie, oblicze społeczne oraz warunki obozowych rygorów, nakładała szczególnie istotne zadania na przedstawicieli elit II RP. Nie ulega wątpliwości, że kluczowe role w sieci polskich instytucji i organizacji w Iranie sprawowali na ogół ludzie ze znaczącym dorobkiem zawodowym w różnych dziedzinach. W artykule wspomniano głównie mężczyzn, którzy pełnili różne funkcje kierownicze i na temat których dysponujemy większą wiedzą biograficzną. Należy jednak zaznaczyć rolę często anonimowych kobiet reprezentantek inteligencji. Na szczególne podkreślenie zasługuje praca nauczycielek i wychowawczyń w placówkach edukacyjnych od przedszkoli do liceów. Pracownice biurowe były niezbędne w funkcjonowaniu administracji placówek.

W źródłach odnaleźć można wiele krytycznych opinii na temat osób sprawujących kierownicze stanowiska w polskim aparacie rządowym w Iranie. Nie ulega wątpliwości, że jego funkcjonowanie utrudniały rozgrywki i swary o charakterze politycznym i personalnym. Faktem jest, że nie ominęły aparatu rządowego takie zjawiska, jak upartyjnienie, nadużywanie władzy, nadużycia gospodarcze, przerosty w administracji, protekcja w obsadzie stanowisk. Nie zawsze też w pełni wykorzystywano umiejętności i doświadczenie uchodźców, część stopniowo delegowano do nowych zadań poza Iranem ${ }^{103}$. Należy jednak pamiętać, że pomimo dramatycznych początków w dość krótkim czasie zapewniono migrantom znośne warunki socjalne, odniesiono wielki sukces w walce o zdrowie uchodźców i wreszcie zapewniono im

99 Właściciel ziemski na Wileńszczyźnie, działacz akademickiego środowiska konserwatywnego („Myśl Mocarstwowa”), autor tekstów piosenek, mąż Hanki Ordonówny. L. G a w lik ow s ki, Pracownicy Radia Wolna Europa. Biografie zwykle i niezwykte, Warszawa 2015, s. 687-692.

${ }^{100}$ Ziemianin z Nowogródczyzny, poseł i senator. K. Rdułtowski, Notatki z wygnania, red. A. Kuczyński, oprac. S. Ciesielski, A. Srebrakowski, Wrocław 1996; A. Piber, Rdultowski Konstanty Piotr (1880-1953) [w:] PSB, t. 30, Wrocław 1987, s. 688; J. Pi i trzak, Parlamentarzyści..., s. 195.

${ }^{101}$ Ziemianin wołyński, senator. J. P i etrzak, Parlamentarzyści..., s. 195-196.

102 J. P i etrzak, Zespót Pracy nad Odbudową Polski (1942-1945). Z dziejów polskiego uchodźstwa wojennego w Iranie, „Imponderabilia. Biuletyn Piłsudczykowski” 2011, nr 3, s. 132-142. Współtwórcami ZPnOP byli także m.in.: b. minister spraw zagranicznych Eustachy Sapieha (wyjechał do Afryki) oraz W. Jaszczołt i Z. Krzysztoporski.

${ }^{103}$ Na przykład W. Styburski został delegatem MPiOS w Indiach, B. Skalak - wiceprzewodniczącym i p.o. przewodniczącego Rady Narodowej, O. Pehr - szefem gabinetu premiera T. Arciszewskiego. 
możliwość realizacji potrzeb edukacyjnych i kulturalnych. Osiągnięcia te były dziełem przedstawicieli różnych grup polskiej inteligencji. Warto zauważyć, że niektórzy z nich wnieśli także znaczący wkład w dorobek społeczno-kulturalny, naukowy i polityczny powojennej emigracji niepodległościowej ${ }^{104}$.

\section{BIBLIOGRAFIA}

\section{Źródła archiwalne}

Archiwum Akt Nowych w Warszawie

Poselstwo RP w Teheranie

Instytut Polski i Muzeum im. gen. Sikorskiego w Londynie

A 7 Ambasada RP w ZSRR

Biblioteka Polska (POSK) w Londynie

Archiwum Osobowe Emigracji

\section{Wydawnictwa źródłowe}

Liga Narodowa (1893-1928). Wybór relacji, oprac. T. Sikorski, A. Wątor, Warszawa 2015.

Polacy w Iranie 1942-1945, t. 1: Antologia, oprac. A.K. Ku nert, Warszawa 2002.

\section{Wspomnienia}

Czarnow ski C., Strzepy wspomnień. Szkice autobiograficzne, Warszawa 1973.

Kaw e cki B., Ze wspomnień wileńskiego prokuratora, Londyn 1977.

Machalski F., Wędrówki irańskie, Warszawa 1960.

Morelow ski J., Sędzia za kratami. Wspomnienia z lat 1939-1942, Nowy York 1970.

Pi ekarski H., Znad Niemna przez Syberię do Kanady, Roma 1967.

Rdułtowski K., Notatki z wygnania, red. A. Kuczyński, oprac. S. Ciesielski, A. Srebrakowski, Wrocław 1996.

\section{Słowniki biograficzne i encyklopedie}

Błaszczyk L.T., Żydzi w kulturze muzycznej ziem polskich w XIX i XX wieku. Stownik biograficzny, Warszawa 2014.

${ }^{104}$ Można wymienić np. uczonych (S. Kościałkowski, W. Sukiennicki, S. Swianiewicz, W. Turek, J. Hoffman), działaczy społeczno-politycznych (A. Pająk, F. Wilk, A. Treszka). 
Cygan W.K., Oficerowie Legionów Polskich 1914-1917. Słownik biograficzny, t. 1, Warszawa 2005.

Gawlikowski L., Pracownicy Radia Wolna Europa. Biografie zwykte i niezwykte, Warszawa 2015.

J u d y c ki Z.A., Polscy duchowni w świecie. Stownik biograficzny, t. 1, Kielce 2008.

Leksykon pitsudczykowski, t. 1: Słownik biograficzny, red. J.H. Szlachetko, K. Dziuda, K. P is kała, Gdańsk 2015

Polski słownik biograficzny, t. 12, 25, 30, 34, 37, 45-46, 48.

Przy by s zew s k i K., Ludzie Torunia Odrodzonej Rzeczypospolitej (1920-1939), cz. 2: Biogramy i szkice biograficzne, Torun 2018.

R a dw ań s k a - P ary s ka Z., P a ry s ki W.H., Wielka encyklopedia tatrzańska, Poronin 2004.

Stownik biograficzny działaczy polskiego ruchu robotniczego, red. F. Ty c h, t. 1-2, Warszawa 1978-1987.

Stownik biograficzny działaczy ruchu ludowego, Warszawa 1989.

Stownik historyków polskich, red. M. Prosińs k a - J a ck1, Warszawa 1994.

W in cła w s k i W., Słownik biograficzny socjologii polskiej, t. 4, Toruń 2011.

\section{Opracowania}

B oćkowski D., Czas nadziei. Obywatele Rzeczypospolitej Polskiej w ZSRR i opieka nad nimi placówek polskich 1940-1943, Warszawa 1999.

B u c ze k R., Stronnictwo Ludowe w latach 1939-1945. Organizacja i polityka, Londyn 1975.

Czarnik O.S., W drodze do utraconej Itaki. Prasa, ksiażki, czytelnictwo na szlaku Samodzielnej Brygady Strzelców Karpackich (1940-1942) oraz Armii Polskiej na Wschodzie i 2 Korpusu (1941-1946), Warszawa 2012.

Demel M., Pamięci Wandy Szuszkiewicz-Ferens (1912-2000), „Kultura Fizyczna” 2002, nr 9-10, s. 25-29.

D o m or adzk i S., S taw is k a M., Distinguished Graduates in Mathematics of Jagiellonian University in the Interwar Period. Part II: 1926-1939, „Technical Transactions. Fundamental Sciences. Czasopismo Techniczne. Nauki podstawowe” 2015, z. 2-NP (20), s. $117-141$.

Draus J., Oświata i nauka polska na Bliskim i Środkowym Wschodzie 1939-1950, Lublin 1993.

Drau s J., Towarzystwo Studiów Irańskich w latach 1942-1945, „Roczniki Nauk Społecznych" 1985 , t. 13 , z. 2, s. 59-72.

Drau s J., Uniwersytet Jana Kazimierza we Lwowie w latach 1939-1944, „Prace Komisji Historii Nauki PAU" 2006, t. 7, s. 105-128.

Feliks Kollat (1895-1975), „Polska Gazeta Transportowa” 2005, nr 26, s. 8.

Głow a cki A., Sowieci wobec Polaków na ziemiach wschodnich II Rzeczypospolitej 19391941, Łódź 1997.

Heydenkorn B., Wiktor Turek (1910-1963), „Canadian Slavonic Papers” 1964, vol. 6, s. 99-100.

Inwentarz akt Antoniego Pająka (premiera rządu Rzeczypospolitej Polskiej na uchodźstwie) i jego rodziny z lat 1919-2001, oprac. E. Koł o d zi ej, B. N ow oży c k i, Warszawa 2008.

Isfahan - miasto polskich dzieci, red. I. Beaupré-Stankiewicz, D. WaszczukKamieniecka, J. Lewicka-Howells, Londyn 1987.

Ka c z mars ki K., O Wielka Polskę na wojennym wychodźstwie. Stronnictwo Narodowe wobec rządu gen. Władysława Sikorskiego (1939-1943), Rzeszów 2013. 
Kalbarczyk S., Martyrologia Polaków w więzieniu przy ulicy Łąckiego we Lwowie w latach II wojny światowej, „Biuletyn IPN” 2010, nr 7-8, s. 108-117.

Kalbarczyk S., Polscy pracownicy nauki - ofiary zbrodni sowieckich w latach II wojny światowej: zamordowani, więzieni, deportowani, Warszawa 2001.

Krasnow ols k a A., Polacy w Iranie w czasie II wojny światowej. Stereotypy i doświadczenia [w:] Dziedzictwo Odyseusza. Podróż, obcość i tożsamość, identyfikacja, przestrzeń, red. M. Cieśla-K ory tow s ka, O. Pła s z c zew s ka, Kraków 2007, s. 369-383.

Kruszyński M., The State of Health of Poles Evacuated from Russia to Persia in 1942, „Antemurale” 1976, vol. 20, s. 133-205.

Krzyżanowski L., Sędziowie II Rzeczypospolitej. Okregi apelacyjne: krakowski i katowicki, Katowice 2011.

Kuhnke M., Cenne, bezcenne, pozyskane, „Cenne, Bezcenne, Utracone” 2002, nr 5, s. 5.

Kula H.M., Gdańska ,dziura celna”. Polscy inspektorzy celni w Wolnym Mieście Gdańsku 1920-1939, Gdańsk 1999.

Le lińska A., Uchodźcy polscy w Iranie w latach 1942-1945, „Przegląd Polonijny” 1993, R. 19, z. 1, s. 69-92.

Machalski F., Z ziemi perskiej do Polski. Wybór tekstów, oprac. K. i K. Paraskiew icz, Kraków 2016.

Mazur G., Życie polityczne polskiego Lwowa 1918-1939, Kraków 2007.

M i er zw a J., Stownik biograficzny starostów Drugiej Rzeczypospolitej, t. 1, Łomianki 2018.

Milewska-Młynik A., Jakub Hoffman - Wolyniak z wyboru, spolecznik z powolania, „Wrocławskie Studia Wschodnie” 2010, t. 14, s. 141-167.

Mironowi c z A., Działalność ks. Michała Bożerianowa na terenie Iranu i Afryki Wschodniej w latach 1941-1945, „Białoruskie Zeszyty Historyczne” 2014, t. 42, s. 137-165.

P i etrzak J., Parlamentarzyści Drugiej Rzeczypospolitej Polskiej na tułaczych szlakach Bliskiego Wschodu [w:] Druga Rzeczpospolita i nie tylko. Ludzie, środowiska, idee. Profesorowi Pawłowi Samusiowi w 70 rocznice urodzin - uczniowie, red. J. Pi etrzak, Łódź 2016, s. 181-203.

Pietrzak J., Polscy uchodźcy na Bliskim Wschodzie $w$ latach drugiej wojny światowej. Ośrodki, instytucje, organizacje, Łódź 2012.

Pietrzak J., Zespół Pracy nad Odbudowa Polski (1942-1945). Z dziejów polskiego uchodźstwa wojennego w Iranie, „Imponderabilia. Biuletyn Piłsudczykowski” 2011, nr 3, s. 132-142.

Pilarski S., Ocalony z ,nieludzkiej ziemi” - losy inspektora Policji Państwowej Józefa Torwińskiego, „Dzieje Najnowsze” 2015, t. 47, nr 2, s. 45-56.

Polacy w Iranie 1942-1945, t. 1: Antologia, oprac. A.K. Ku ne rt, Warszawa 2002.

Portalski S., Zarys historii Polskiego Towarzystwa Naukowego na Obczyźnie, Londyn 2009.

Redzik A., Prokuratoria Skarbu - Prokuratoria Generalna Rzeczypospolitej Polskiej oddział we Lwowie. Szkic o dziejach instytucji [w:] Lwów. Miasto, spoteczeństwo, kultura. Studia z dziejów Lwowa, t. 7: Urzędy, urzędnicy, instytucje, red. K. Kazimierczak, Ł.T. S roka, Kraków 2010, s. 144-156.

Rymarz F., Adwokatura lubelska $w$ okresie dwudziestolecia międzywojennego (19181939), „Palestra” 1988, t. 37, nr 7(367), s. 3-28.

S i enki ew ic z J.W., Wyprowadzeni z nieludzkiej ziemi: artyści wokół Andersa, „Sztuka Europy Wschodniej" 2014, t. 2, s. 409-417.

Stanisław Kościałkowski pamięci przywrócony, red. M. Dąbrowska, Warszawa-Łódź 2016.

Supruniuk M.A., Nauka polska na Bliskim i Środkowym Wschodzie w latach 1942-1949, cz. I: Persja, „Opuscula Musealia” 2014, t. 22, s. 45-71. 
Ś ródka A., Wspomnienia pośmiertne: Jakub Węgierko (1889-1960), „Rocznik Towarzystwa Naukowego Warszawskiego" 1983, t. 46, s. 298-303.

Urzyńska D., Powstanie polskich struktur politycznych $w$ Iranie w czasie II wojny światowej (Na przykładzie Polskiej Partii Socjalistycznej), „Przegląd Wschodni” 2002, z. 1, s. $137-154$.

Walkusz J., Niezłomny żotnierz na Bożym posterunku. Ks. Jan Achtabowski 1909-1998, „Duszpasterz Polski Zagranicą” 1999, t. 50, nr 3, s. 405-410.

Wawrzyniak J., Śrem w Powstaniu Wielkopolskim, Śrem 2011.

Wi erzbiański B., Słowo wstępne [w:] J. Morelows ki, Poezje, N. York 1988.

Witale c R., Franciszek Wilk 1914-1990. Biografia ludowca niezłomnego, Rzeszów-Warszawa 2015.

Wróbel J., Uchodźcy polscy ze Zwiąku Sowieckiego 1942-1950, Łódź 2003.

$\dot{Z}$ arnow s ki J., Inteligencja polska jako elita kulturalna i społeczna $w$ ostatnich stu latach, red. W. Mędrze cki, Warszawa 2019 (Metamorfozy Społeczne, t. 24).

Żarnowski J., Struktura społeczna inteligencji w Polsce $w$ latach 1918-1939, Warszawa 1964.

\section{Netografia}

[Abramowicz Kazimierz] [w:] Album Polonorum, t. 1, www.konwentpolonia.pl/album-polonorum/kazimierz-abramowicz [dostęp: 9 IV 2020 r.].

[Kawecki Bohdan] Archiwum Korporacyjne. Archiwum i Muzeum Polskich Korporacji Akademickich, www.archiwumkorporacyjne.pl/index.php/muzeum-korporacyjne/wilno/ k-cresovia/ [dostęp: 9 IV 2020 r.].

Krahel T., Ks. Franciszek Tomasik-salezjanin z Supraśla, „W Służbie Miłosierdzia” 2006, nr 1, www.wsm.archibial.pl/wsm16/art.php?id_artykul=195 [dostęp: 18 IV 2020 r.].

Kra sn ow ols k a A., Machalski Franciszek (1904-1979) [w:] Encyclopaedia Iranica, www. iranica.online.org/articles/machalski-franciszek [dostęp: 30 III 2020 r.]. 
